\title{
Standardization, Development and Proximate Composition of Baked Value Added Products by Using Indian Horse Chestnut (Aesculus indica) Flour
}

\author{
Manju Lata Mishra ${ }^{*}$, Sangita Sood ${ }^{1}$ and U.N. Shukla ${ }^{2}$ \\ ${ }^{l}$ FSN\&T, College of Home Science, CSK HPKV, Palampur (H.P.), India \\ 2(Agronomy), College of Agriculture, Jodhpur (RAJ.), India \\ *Corresponding author
}

A B S T R A C T

Ke y w o r d s
$\begin{aligned} & \text { Aesulus indica, } \\ & \text { Bakery, Proximate } \\ & \text { composition, Sensory, } \\ & \text { Tatwakhar, Value } \\ & \text { added products }\end{aligned}$
Article Info
$\begin{aligned} & \text { Accepted: } \\ & \text { 15 January } 2018 \\ & \text { Available Online: } \\ & \text { 10 February } 2018\end{aligned}$

\section{Introduction}

In India, Aesculus indica is known as Indian Horse Chest and member of Hippocastanaceae family. It is widely grown at high altitude or in temperate region of Europe, America, and partially in East Asia, North Western Himalaya, and North America as Majeed et al., (2009). Although all parts of the tree is used for food, feed and fodder. Basically, other varieties of seeds were used to extract (HCSE), and its main active chemical constituent, aescin (a saponin mixture) is used in the treatment of chronic venous insufficiency, hemorrhoids, and postoperative edema (Zhang et al., 2010). Syed et al., (2016) reported the physical parameters of the Horse Chestnut; the weight of seed was $40.8 \mathrm{~g}$, while kernel and shell per cent were 85.71 and 14.29, respectively. Rajasekaran and Singh (2009) revealed the traditional method of preparation of the flour; the seeds are crushed and soaked in water for five to seven consecutive days and change the water daily. The seeds are dried and grounded into flour, called tatwakhar in some parts of Himachal Pradesh. This flour is bitter and used for making halwa, and taken in phalahar (non- 
cereal food) during fasts. Majeed et al., (2010) estimated the nutritional and mineral composition of raw seed as nitrogen $(1.15 \%)$, crude protein $(7.18 \%)$, potassium $(0.79 \%)$, phosphorus $(0.18 \%)$, sulphur $(0.07 \%)$, calcium $(0.08 \%)$, iron (159 ppm), copper (41.2 ppm), zinc (25.6 ppm) and manganese (6.95) $\mathrm{ppm}$ ) with 2.02 per cent oil. Whereas, the aescin content of the processed flour was 0.08 per cent as found by Sood et al., (2015), this tends to be negligible for its toxicity and good for health. The seeds are particularly rich in sugars, full of starch and toxic compounds such as saponins which makes it flour bitter and unpalatable for edible purposes; followed by several treatments like soaking, blanching, cooking, and pressure cooking were standardized as well as traditional techniques to remove the saponins content by Thakur et al., (2015). Each and every year seeds are wastes due to presence of its toxic components like saponin, tannin etc. But after processing, the seeds toxicity can be removed and fit for human consumption. It is good option for gluten sensitive patients who have limited food source for their survival. Sacchetti et al., (2004) tried to make snack-like products by extrusion-cooking of chestnut-rice flour blendbased dough, in order to obtain adequate puffing. It was found that extrusion-cooking process rice flour with $30(\%)$ chestnut flour was good by a sensory panel. Normally, all bakery products are made by the use of refined flour or maida but an endeavor was made to explore the processed flour (25 to $100 \%$ ) with food recipes for the development of value added products and adds food variety, food as well as nutritional security for well-being.

\section{Materials and Methods}

\section{Standardization and product development of value added products}

Various recipes were developed and standardized by the use of the maida, besan, wheat flour, and processed flour (tatwakhar). Locally, people used to eat halwa from the flour. Efforts were made to develop different type of products from the flour of Indian Horse Chestnut. Recipes were standardized by using different permutation and combination to get the desirable texture, taste, flavour and colour of the final product.

\section{Standardization of Recipes}

An effort was made to standardize and compare the value added products prepared from processed flour (tatwakhar) of Indian Horse Chestnut (Aesculus indica).

As control sample was made from maida, besan, and wheat flour.

\section{Energy bar}

Take almonds (50g) and peanut (50g), in mixer and chopped finely and transferred into bowl. In this bowl, processed flour $(60 \mathrm{~g})$, besan (170g), milk powder $(25 \mathrm{~g})$ was premixes and then added syrup $(80 \mathrm{ml})$ and combined well all ingredients. Oven was pre heated at $180^{\circ} \mathrm{C}$. Baking pan was greased with ghee. Mixture was poured into greased baking pan and spread evenly. Baked until it turned in to golden brown in color.

\section{Short bread}

Firstly, creamed together butter $(90 \mathrm{~g})$ and icing sugar $(28 \mathrm{~g})$ till light and fluffy. Added processed flour $(100 \mathrm{~g})$ mixed well and kneaded dough. Dough was wrapped in plastic wrap and placed in fridge for $1 / 2$ hour. After that the dough was removed from fridge and rolled out and shaped into a log. Spread sesame seeds $(2 \mathrm{~g})$ over it. Baking tray was lined with baking paper, place desired short bread on tray. Baked at $180^{\circ} \mathrm{C}$ for 15 minutes or until turned into pale golden and not to overcook. Allowed to cool and cut into slices. 


\section{Brownies}

Sift the processed flour (140g), baking powder $(2.5 \mathrm{~g})$ and salt (1 pinch) three times. Creamed together with butter $(90 \mathrm{~g})$ and sugar $(160 \mathrm{~g})$ until light and fluffy.

Added sifted flour, Cocoa (12g), Almond/ dry fruit dry $(40 \mathrm{~g})$ slowly, blended well. Folded in nuts and added vanilla essence $(2 \mathrm{ml})$.

The mixture was divided into small sized balls and pressed into desirable size. Baked at $180^{\circ} \mathrm{C}$ for 30 minutes, or until toothpick stuck in middle came out clean and allowed to cool.

\section{Cookies}

The processed flour $150 \mathrm{~g}$ was sieved. The butter $(100 \mathrm{~g})$ and sugar $(50 \mathrm{~g})$ were beaten until gets light and fluffy. Added the vanilla essence $(2.5 \mathrm{ml})$ and beat it again. Added cashew nuts or almond powdered (50 g), processed flour and mixed well. Rolled out the dough into $6 \mathrm{~mm}$ thickness. Cut with a round cookie cutter; make a hole in the centre of each round with help of a nozzle. Greased and dust a baking tin and arrange the cookies in it. Bake in an oven at $180^{\circ} \mathrm{C}$ for 25 minutes and allowed to cool the cookies.

\section{Chocolate cake}

Preheated the oven to $180^{\circ} \mathrm{C}$. simultaneously greased and dusted a cake tin with flour. Took a large bowl and mixed with the processed flour $100 \mathrm{~g})$, caster sugar $(100 \mathrm{~g})$, cocoa powder $(15 \mathrm{~g})$, salt (a pinch) and baking soda (1.6g). Made a well in the centre, and poured vegetable oil/ butter $(31.25 \mathrm{ml})$, water (For consistency) and vanilla essence $(2.5 \mathrm{ml})$ in it.

Mixed well, and then poured into the cake tin. Baked for 30-40 minutes, or until cook or a skewer inserted into the centre comes out clean.

\section{Cup cake}

Pre heated the oven to $180^{\circ} \mathrm{C}$. Greased moulds with butter. In separate bowl, cream butter $(50 \mathrm{~g})$ and sugar $(50 \mathrm{~g})$ was placed in bowl until fluffy. Sifted the milk powder $(60 \mathrm{~g})$ into a bowl and continued to mix. Sifted the processed flour $(100 \mathrm{~g})$, baking powder $(5 \mathrm{~g})$, cardamom powder $(1.25 \mathrm{~g})$ into the bowl. Added little milk (15ml) to adjust its consistency and mixed well.

The batter was poured into greased moulds. Taped the mould lightly to level the batter. Baked for 30 minutes. Removed from the moulds and cooled it. Serve warm or cold.

\section{Jamie bodgers}

Sifted the processed flour (100g) into a bowl and rubbed the butter $(25 \mathrm{~g})$ with finger tips. Sugar $(65 \mathrm{~g})$, vanilla essence $(5 \mathrm{ml})$ were added and mixed into a soft dough. Kneaded the dough gently on to a light floured surface until smooth. Pre heated the oven to $180{ }^{\circ} \mathrm{C}$. Greased the tray with butter. Rolled out the dough thinly on a lightly floured surface and cut into round with the help of cutter.

Rerolled the trimmings and cut into more rounds. Made cookies whole and with hole at the centre. Beated together the butter $(50 \mathrm{~g})$ and sugar $(50 \mathrm{~g})$ until smooth and creamy.

Spreaded the butter cream evenly on the whole cookies. Spoon a jam (70-75g) over the butter cream for fillings. And placed the cut out cookies on top, pressed gently. So that the jam filled the heart shaped space.

\section{Sensory evaluation}

The prepared products were evaluated organoleptically by randomly chosen ten panelists by using the method suggested by Gould (1978) as in Table 1. 


\section{Proximate analysis}

The processed flour and their value added products were analyzed for the Moisture, Ash, Protein Fat and Carbohydrate (NFE) by using standard methods of (AOAC, 1990). The crude protein was calculated by multiplying nitrogen per cent with 6.25 factor.

\section{Experimental layout}

The experiment was scientifically planned and laid out according to CRD design. In order to reduce the determinate type of error, for each type of parameter, observations were replicated thrice. The prepared products were evaluated for its sensory characteristics viz. colour, appearance, texture, flavor, taste and overall acceptability for all samples by the randomly chosen ten panelists. Organoleptic evaluation form which consist of 0 to 10 marks.

The test sample was given in triplicates with control or standard. Standard sample was prepared from the normal or usual recipes. All samples were coded to avoid any bias judgment.

\section{Statistical analysis}

The data collected on all the parameters viz., proximate analysis and sensory evaluation were analyzed statistically. Analysis of variance by completely randomized design (CRD) in which the mean and critical difference (CD) value was determined and their statistical significance was ascertained.

\section{Results and Discussion}

The study was mainly based on the standardization and development of value added products namely Energy Bar, Short Bread, Brownies, Cookies, Chocolate Cake, Cup Cake, and Jamie Bodgers by using the
Indian horse chestnut flour (tatwakhar). The developed products were tested for their organoleptic evaluation for the most acceptable level from the usual recipes and the prepared products were analyzed for their nutritional composition as well.

\section{Organoleptic evaluation of processed flour (Tatwakhar) of Indian horse chestnut}

All the value added products were prepared by using ingredients maida, besan and wheat flour for control samples and for the test samples, the standard recipes were replaced by using processed flour at different level to obtained its maximum binding, other properties and organoleptically acceptable by the panel of judges consumers' acceptability for the use of sensory organs such as taste, flavour, colour and texture and over all acceptability.

The average mean scores of the Energy Bar are given in Figure 1 and Short bread in the Table 2 . The test sample was made by the use of 25 per cent processed flour for proper binding of the energy bar.

The mean scores of Energy Bar and Short bread possessed almost similar in colour, flavor, taste, texture and overall acceptability but the taste and texture of the short bread, test sample was more acceptable than the relevant control one. and statistically, no significant difference was found in the both products i.e. Energy Bar and Short Bread prepared from wheat flour, maida and processed flour. The sensory mean scores for the brownie is given in Figure 2. It showed that the consumers' acceptability index for the colour, flavor, taste, texture and overall acceptability of brownie prepared from processed flour was gained highest values than the control sample. Hence, statistically no significant difference was found for the overall acceptability of the brownie prepared from both flours. 
Plates: Standardization and Development of value added products

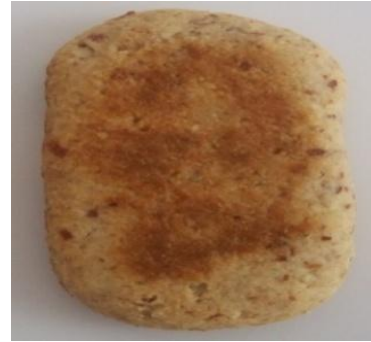

Plate 1(a): Energy bar prepared from wheat flour

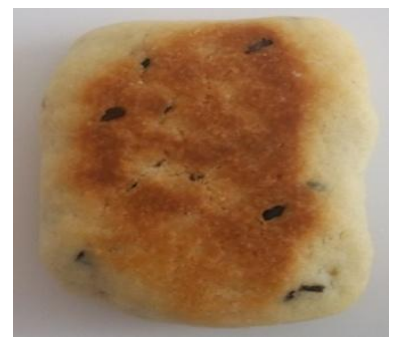

Plate 2 (a): Short bread prepared from maida

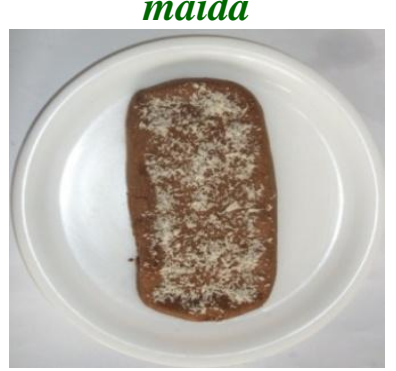

Plate 3 (a): Brownie prepared from maida

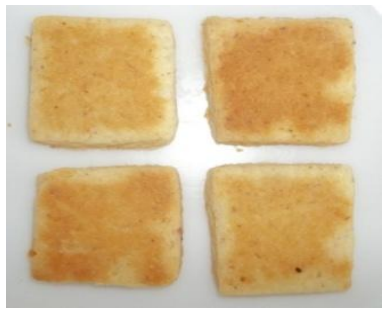

Plate 4 (a): Cookies prepared from maida

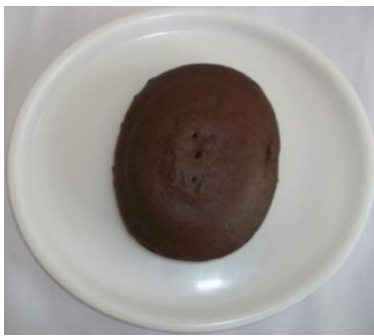

Plate 5 (a): Chocolate cake prepared from maida

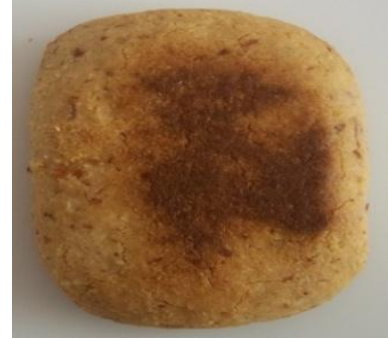

Plate 1(b): Energy bar prepared from processed flour

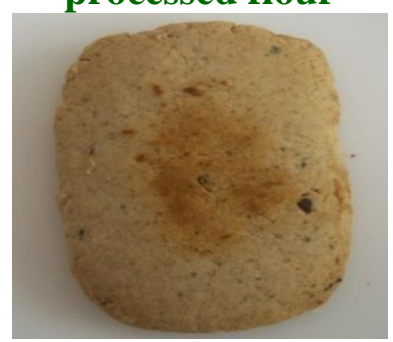

Plate 2 (b): Short bread prepared from processed flour

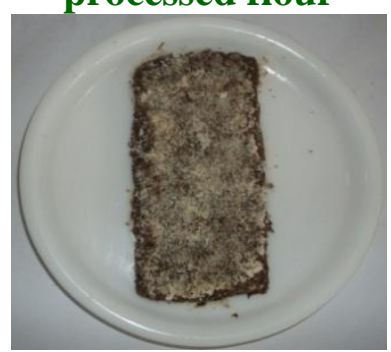

Plate 3 (b): Brownie prepared from processed flour

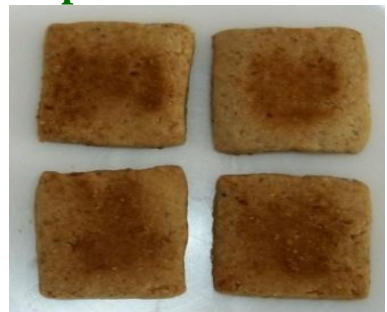

Plate 4 (b): Cookies prepared from processed flour

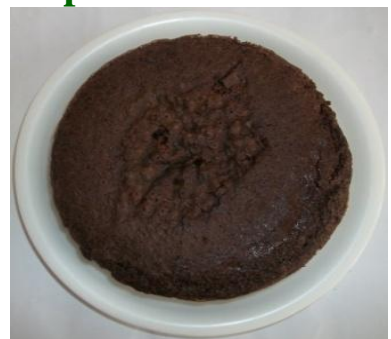

Plate 5 (b): Chocolate cake prepared from processed flour 


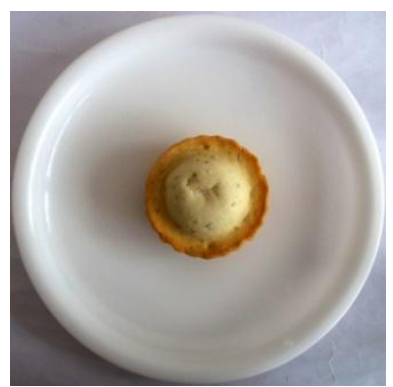

Plate 6(a):Cupcake prepared from maida

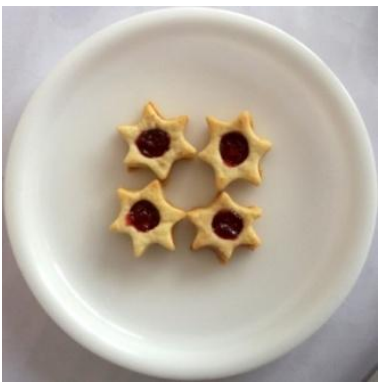

Plate 7 (a): Jamie Bodgers prepared from maida

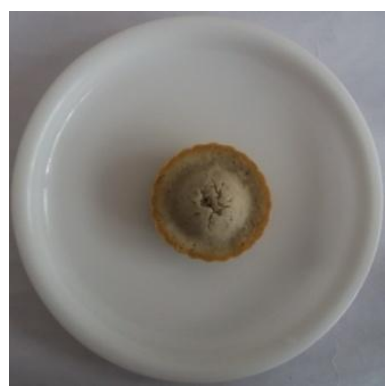

Plate 6 (b):Cupcake prepared from processed flour

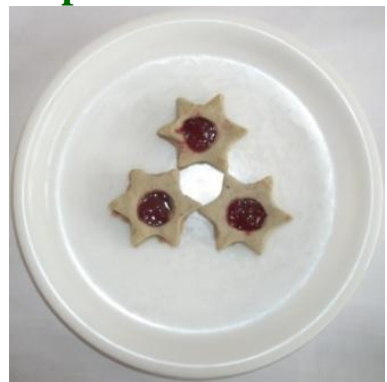

Plate 7 (b): Jamie Bodgers prepared from processed flour

Fig.1 Acceptance index of energy bar

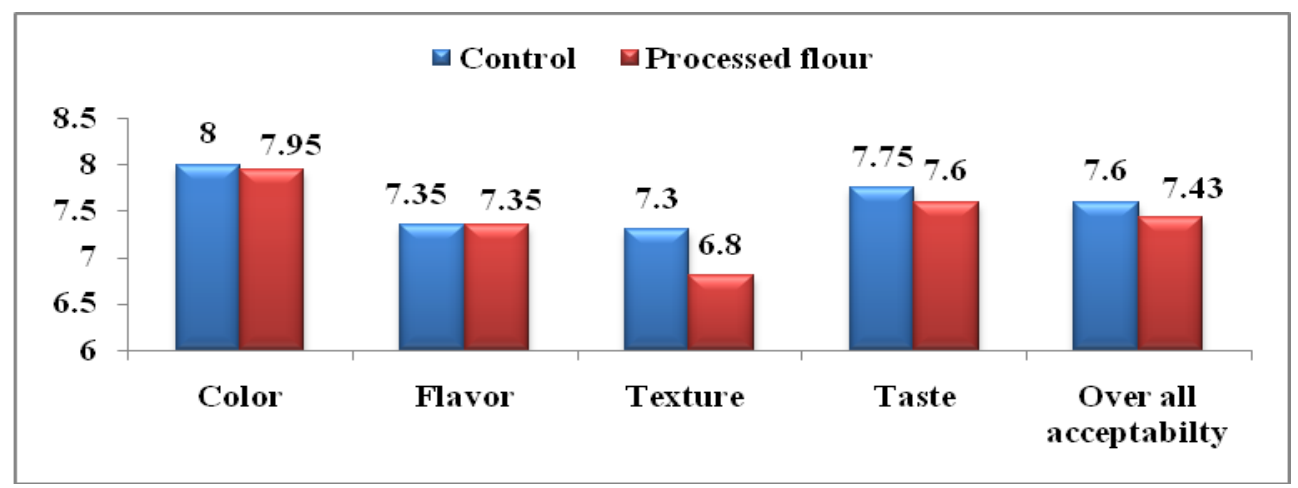

Fig.2 Acceptance index of Brownie

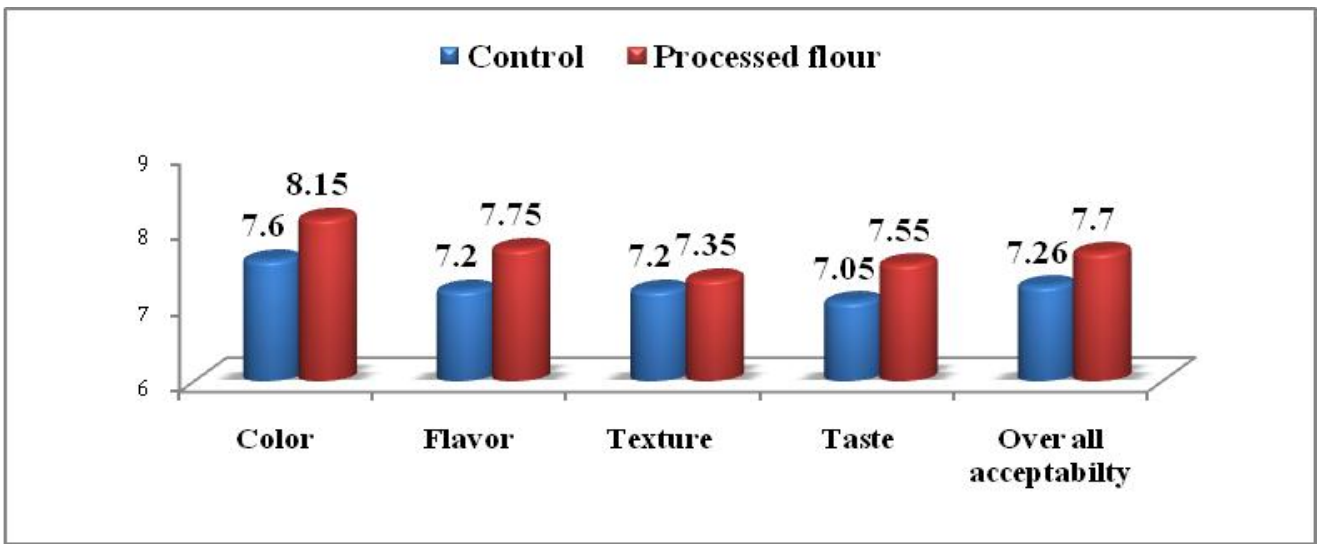


Fig.3 Acceptance index of cookies

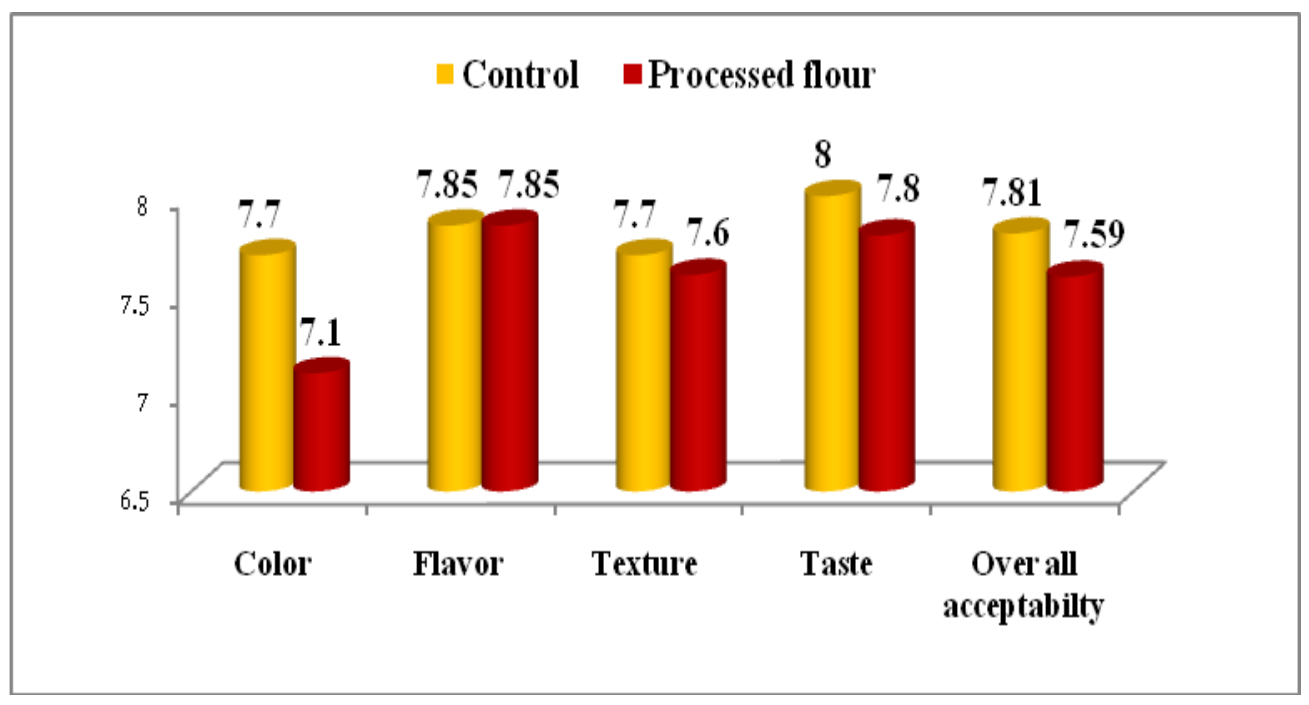

Fig.4 Acceptance index of chocolate cake

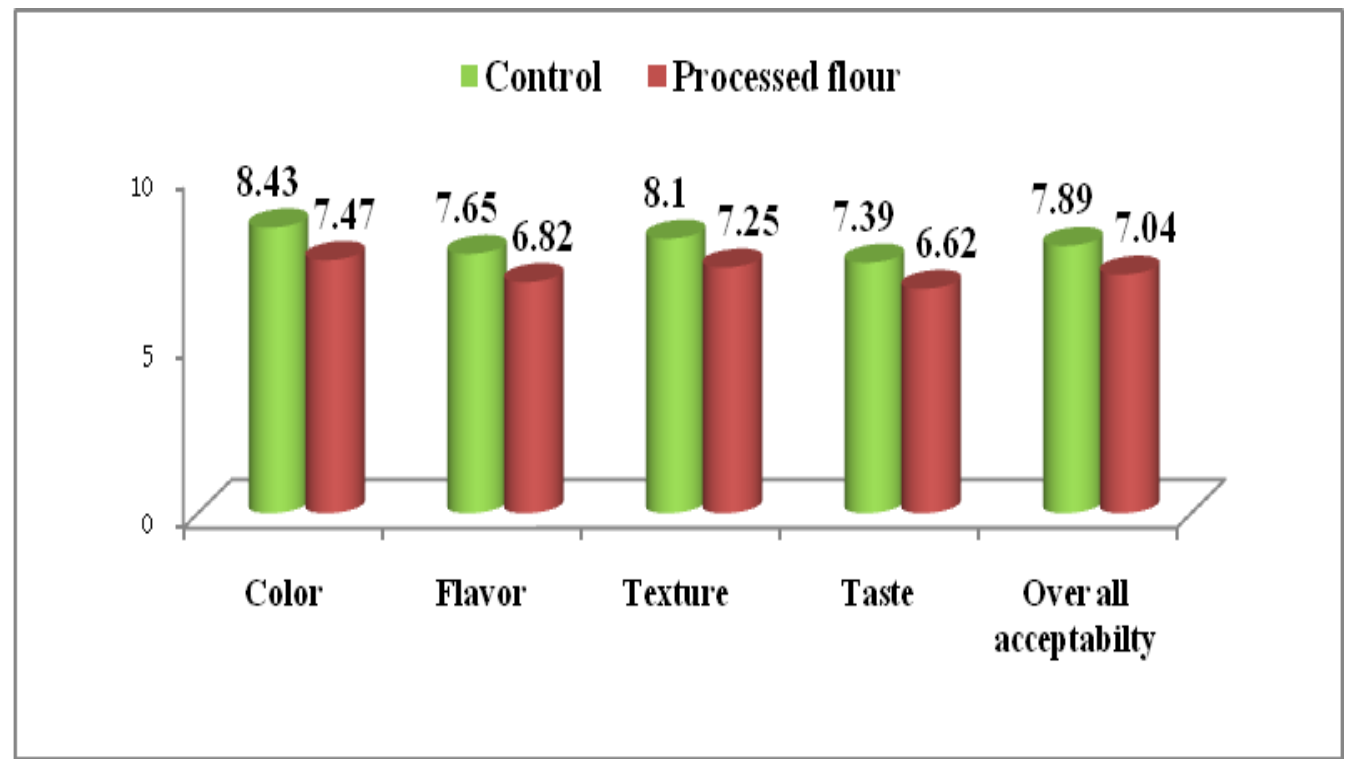

Table.1 Organoleptic evaluation form

Sample:

Date:

\begin{tabular}{|c|c|c|c|c|c|c|c|c|c|c|c|}
\hline Sample & Perfect & \multicolumn{3}{|c|}{ Good } & \multicolumn{3}{|c|}{ Fair } & \multicolumn{2}{|c|}{ Poor } & Off & Remarks \\
\hline & 10 & 9 & 8 & 7 & 6 & 5 & 4 & 3 & 2 & 1 & 0 \\
\hline
\end{tabular}

Note: Make check mark in columns corresponding to your rating of sample, when scorning one factor. However, when scorning 2 or more factors, write in the following letter in the corresponding column of columns (C) colour (E) Flavour (T) Texture (S) Consistency 
Table.2 Organoleptic evaluation of short bread

\begin{tabular}{|c|c|c|c|}
\hline & $\begin{array}{c}\text { Short bread prepared } \\
\text { from maida }\end{array}$ & $\begin{array}{c}\text { Short bread prepared } \\
\text { from processed flour }\end{array}$ & $\begin{array}{c}\text { CD } \\
(\mathbf{P} \leq 0.05)\end{array}$ \\
\hline Colour & 8.10 & 7.50 & NS \\
\hline Flavour & 7.90 & 7.50 & NS \\
\hline Taste & 7.40 & 7.55 & NS \\
\hline Texture & 7.25 & 7.35 & NS \\
\hline Overall acceptability & 7.66 & 7.48 & NS \\
\hline
\end{tabular}

Table.3 Organoleptic evaluation of cup cake

\begin{tabular}{|c|c|c|c|}
\hline & $\begin{array}{c}\text { Cupcake prepared } \\
\text { from maida }\end{array}$ & $\begin{array}{c}\text { Cupcake prepared from } \\
\text { processed flour }\end{array}$ & $\begin{array}{c}\text { CD } \\
(\mathbf{P} \leq \mathbf{0 . 0 5})\end{array}$ \\
\hline Colour & 8.30 & 7.75 & NS \\
\hline Flavour & 7.55 & 7.35 & NS \\
\hline Taste & 8.20 & 7.30 & 0.85 \\
\hline Texture & 8.45 & 7.00 & NS \\
\hline Overall acceptability & 8.13 & 7.35 & 0.76 \\
\hline
\end{tabular}

Table.4 Organoleptic evaluation of Jamie bodgers

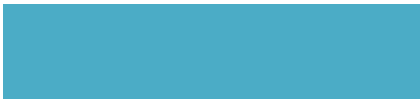

\begin{tabular}{|c|}
\hline Colour \\
\hline Flavour \\
\hline Taste \\
\hline Texture \\
\hline Overall acceptability \\
\hline
\end{tabular}

\begin{tabular}{|c|c|c|}
$\begin{array}{c}\text { Jamie bodgers prepared } \\
\text { from Maida }\end{array}$ & $\begin{array}{c}\text { Jamie bodgers prepared } \\
\text { from Processed flour }\end{array}$ & $\begin{array}{c}\text { CD } \\
(\mathbf{P} \leq 0.05)\end{array}$ \\
\hline 7.80 & 7.00 & NS \\
\hline 7.70 & 6.90 & NS \\
\hline 7.60 & 6.90 & NS \\
\hline 7.80 & 6.60 & 0.81 \\
\hline 7.73 & 6.85 & 0.74 \\
\hline
\end{tabular}

Table.5 Nutritional evaluation of standardized products prepared from processed flour of Indian horse chestnut (Aesculus indica)

\begin{tabular}{|l|c|c|c|c|c|}
\hline Parameter & $\begin{array}{c}\text { Moisture } \\
(\%)\end{array}$ & $\begin{array}{c}\text { Ash } \\
(\%)\end{array}$ & $\begin{array}{c}\text { Fat } \\
(\%)\end{array}$ & $\begin{array}{c}\text { Protein } \\
(\%)\end{array}$ & $\begin{array}{c}\text { Carbohydrate } \\
(\mathbf{\%}) \mathbf{( \% )}\end{array}$ \\
\hline Energy Bar & 4.90 & 1.90 & 29.75 & 35.40 & 28.08 \\
\hline Short Bread & 4.95 & 0.65 & 25.52 & 11.44 & 57.44 \\
\hline Brownies & 5.00 & 2.60 & 27.98 & 31.24 & 33.18 \\
\hline Cookies & 2.10 & 1.75 & 21.31 & 12.63 & 62.21 \\
\hline Chocolate Cake & 7.20 & 1.25 & 30.36 & 6.62 & 54.57 \\
\hline Cup Cake & 14.20 & 2.85 & 20.36 & 17.25 & 45.34 \\
\hline Jamie Bodgers & 9.30 & 1.00 & 12.25 & 10.70 & 66.75 \\
\hline
\end{tabular}

Demirkesen et al., (2010) found that the of 30/70 and containing xanthan-guar blend breads prepared with chestnut/rice flour ratio and emulsifier, had higher quality in terms of 
hardness, specific volume, color and sensory values. As is evident in Figure 3, the sensory mean scores for the colour of the cookies in control one was obtained as 7.70 whereas, test sample got 7.10 , but statistically no significant difference was found. And same score obtained for the flavour in both the samples. Almost similar values of taste and texture were obtained. Statistically, no significant difference was found between the control and test samples. Singh et al., (2011) prepared a cookie prepared from water chestnut flour which is similar to the Indian horse chestnut flour exhibited good acceptance and exceptional scope in forthcoming future in Indian market. From the Figure 4, the mean scores for sensory attributes obtained by the chocolate cake prepared from maida and processed flour were little different. But statistically, No significant difference was found. Cakes prepared with chestnut and rice flour ratio of 30:70 and $150(\%)$ water levels were the most acceptable as studied by Demirkesen et al., (2011). Table 3 showed the organoleptic evaluation and acceptability index of cupcake prepared from maida and processed flour. The mean score for the colour, flavor and texture of the control sample were highest than the test sample. There was no significant difference possessed by this parameter. But when the taste and overall acceptability of the cup cake is concerned; the mean values were differed as 0.85 and 0.76 respectively and varied statistically significantly. Data in Table 4 represented the organoleptic evaluation and acceptance index of Jamie bodgers. Colour, flavor and taste were obtained with statistically no difference but the CD value for the taste and overall acceptability of the control one were as 0.81 and 0.74 respectively. In nutshell, the processed flour (tatwakhar) was found to be best for the bakery products. Ahmad et al., (2017) studied on brown rice and chestnut flour based snacks have good potential for consumer acceptance and are regarded as health promoting functional food, especially for celiac disease patients.

\section{Proximate composition}

The various value added products prepared from processed flour was analyzed for its proximate composition and results are expressed on dry matter basis and presented in Table 4. Moisture and ash content was highest in Cup cake and cookies have lowest moisture value whereas ash was lowest in short bread. The processed flour contains negligible fat so the visible fat added to the ingredients' was highest in chocolate cake with followed by energy bar whereas Jamie bodger possessed lowest fat 12.25(\%) and highest carbohydrate percentages. Protein percentage was fortified in energy bar 35.40 (\%) and brownies 31.24(\%), the lowest with 6.62(\%) (Table 5).

Indian horse chestnut flour is used for making value added products which encourages dietary diversification and medicinal, ethno botanical, and nutritional enhanced food habit system and it is one of the best and effective utilization of the waste and under exploited food stuff. It can be concluded form the prepared products that the sensory scores for energy bar, short bread, cookies, chocolate cakes, cupcakes and Jamie bodger was almost similar with standard recipes and had little or no statistically significance difference. Brownie was found best and most acceptable product when compared to the usual recipes in terms of colour, flavour, taste, texture and overall acceptability. Hence the use of the Indian horse chest nut flour (tatwakhar) will ensure nutritional, food varietal, and income generation. The standardized and developed value added products are good for the bakery industry. Also, in health point of view, it has no gluten and fiber content which can be good food for celiac disease patients' and bland food. 


\section{References}

Ahmad, S.M., Bosco, S.J.D. and Shah, M.A. 2017. Technological and nutritional properties of gluten-free snacks based on brown rice and chestnut flour. Journal of the Saudi Society of Agricultural Sciences (Retrieved from https://doi.org/10.1016/j.jssas.2017.02.002).

AOAC.1990. Official Methods of Analysis. 15th Edn. Association of official analytical chemists, Washington, DC, pp.113-127.

Demirkesen, I., Mert, B., Sumnu, G. and Sahin, S. 2010. Utilization of chestnut flour in gluten-free bread formulations. Journal of Food Engineering 101(3): 329-336.

Demirkesen, I., Sumnu, G. and Sahin, S. 2011. Utilization of chestnut flour in gluten-free cakes. International symposium on towards a sustainable food chain food process, bioprocessing and food quality management, Nantes, France, April, 18-20.

Gould, W.A. 1978. Food Quality Assurance. The AVI publishing company Inc. West port. Connecticut.

Majeed, M., Khan, M.A, Bashir, A. and Hussain A. 2010. Nutritional value and oil content of Indian horse chestnut seed. Global Journal of Science Frontier Research 10:1719.

Majeed, M., Khan, M.A., Mughal, A.H. and Bashir, A. 2009. Maturity Indices of Indian Horse-Chestnut (Aesculus indica Colebr) Seeds under Temperate Kashmir Conditions. Silva Lusitana 17(2): 211 219.

Rajasekaran, A and Singh, J. 2009. Ethnobotany of Indian Horse chestnut (Aesculus indica) in Mandi district, Himachal Pradesh. Indian
Journal of Traditional Knowledge 8: 285286.

Sacchetti, G., Pinnavaia, G.G., Guidolin, E. and Dalla-Rosa, M. 2004. Effects of extrusion temperature and feed composition on the functional, physical and sensory properties of chestnut and rice flour-based snack-like products. Food Research International 37: 527-534.

Singh, G.D., Riar, C.S., Saini, C., Bawa, A.S., Sogi, D.S. and Saxena, D.C. 2011. Indian water chestnut flour- method optimization for preparation, its physicochemical, morphological, pasting properties and its potential in cookies preparation. Food Science and Technology 44 (3): 665-672.

Sood, S., Mishra, M., Sood, A. and Thakur, V. 2015. Hypoglycaemic and hypocholesterolimic efficacy of horse chestnut (Aesculus indica) using rat model. Journal of Clinical Nutrition and Dietetics 1(1):1-8.

Syed, I.R., Sukhcharn, S. and Saxena, D.C. 2016. Evaluation of physical and compositional properties of Horse-chestnut (Aesculus indica). Seed. J Food Process Technol 7: 561

Thakur, N.S., Kumar, P. and Joshi, V.K. 2015. Improvement of traditional methods for the development of edible flour from Indian horse chestnut (Aesculus indica). Intl. J. Food. Ferment. Technol. 5(2): 169-176.

Zhang, Z., Shiyou, L. and Xiao-Yuan, L. 2010. An overview of genus Aesculus L.: Ethanobotany, phytochemistry and pharmacological Activities. Pharmaceutical Crops 1: 24-51.

\section{How to cite this article:}

Manju Lata Mishra, Sangita Sood and Shukla, U.N. 2018. Standardization, Development and Proximate Composition of Baked Value Added Products by Using Indian Horse Chestnut (Aesculus indica) Flour. Int.J.Curr.Microbiol.App.Sci. 7(02): 1449-1458.

doi: https://doi.org/10.20546/ijcmas.2018.702.175 